\title{
Optimal Process Network for Integrated Solid Waste Management in Davao City, Philippines
}

\author{
Kristin Faye Olalo ${ }^{\dagger}$, Jun Nakatani $*$ (D) and Tsuyoshi Fujita
}

check for updates

Citation: Olalo, K.F.; Nakatani, J.; Fujita, T. Optimal Process Network for Integrated Solid Waste Management in Davao City, Philippines. Sustainability 2022, 14 , 2419. https://doi.org/10.3390/ su14042419

Academic Editor: Luis Garrote

Received: 27 January 2022

Accepted: 15 February 2022

Published: 20 February 2022

Publisher's Note: MDPI stays neutral with regard to jurisdictional claims in published maps and institutional affiliations.

Copyright: (c) 2022 by the authors. Licensee MDPI, Basel, Switzerland. This article is an open access article distributed under the terms and conditions of the Creative Commons Attribution (CC BY) license (https:// creativecommons.org/licenses/by/ $4.0 /)$.
Department of Urban Engineering, The University of Tokyo, Tokyo 113-8656, Japan; olalo@env.t.u-tokyo.ac.jp (K.F.O.); fujita77@env.t.u-tokyo.ac.jp (T.F.)

* Correspondence: nakatani@env.t.u-tokyo.ac.jp

+ Present address: Department of Architecture, University of the Philippines Mindanao, Davao City 8026, Philippines.

\begin{abstract}
Municipal solid waste management (MSWM) systems in developing countries adopt practices from developed countries to reduce their environmental burdens. However, several complex issues specific to developing countries hinder the full implementation of these practices. The future of MSWM in Davao City, Philippines, is envisaged as a notable example of the combination of new infrastructure and local MSWM practices. A linear programming model was developed, following material flow analysis and life cycle assessment, to design an optimal system for Davao City. The performance of the system was evaluated in terms of greenhouse gas emissions, energy and revenue generated, and the amount of landfill waste. The results show that the proposed system positively affects the environment compared to the current system, due to additional treatment options. However, the main allocation concern transitions from organic waste in the current system to plastic waste in future scenarios. Furthermore, the mitigation of greenhouse gas emissions and the extension of landfill life will be heavily influenced by trade-offs between sorting operations and the management of incinerated wastes with high calorific values. Therefore, plastic-waste-specific treatment options will be critical for future MSWM systems. The results herein underscore the need for sustainable MSWM in the study area, considering the region-specific conditions.
\end{abstract}

Keywords: greenhouse gases; integrated solid waste management; life cycle assessment; linear programming; material flow analysis; separation rate

\section{Introduction}

Municipal solid waste management (MSWM) has become an important environmental issue in many developing countries. The threat of global climate change has prompted changes in MSWM systems as one way to reduce greenhouse gas (GHG) emissions. In response, a modernization trend is emerging in the urban areas of developing countries to adopt the experience of developed countries and their integrated solid waste management systems as global best practices [1]. There is also a growing interest in creating environmentally friendly MSWM and resource conservation through improved infrastructure systems, the application of technologies such as incineration, and the use of scientifically derived process networks [2-4].

However, applying current methodologies from developed countries to developing countries presents many obstacles to full implementation, due to the complexity of the situation in developing countries. These complexities include rapid economic growth, high urbanization rates, differences in waste composition, a lack of proper governance, the presence of an informal sector, and a lack of financial resources [1,5-10]. Therefore, MSWM systems need to be adapted to best suit the socio-economic conditions of the region wherein these future improvements will be realized [11,12].

Davao City is a notable example of this current and future waste situation. As the capital of the third-largest metropolitan area in the Philippines, Davao is expected to face 
the consequences of rapid waste generation and a lack of waste-related infrastructure. With a projected population of 1.7 million in 2017, the city's waste generation has already reached 991 tons per day (TPD) and is expected to increase further as its population and economy grow. The emergence of this new threat led to a plan to integrate MSWM services, as indicated in the Davao City Ecological Solid Waste Management Plan (ESWMP) for the 10-year period from 2018 to 2027 [13]. Some of the goals identified to support this plan are improving waste separation and reduction at source, increasing waste diversion toward composting and recycling facilities and enhancing MSWM through new waste-to-energy (WTE) and sanitary landfill facilities.

This plan shall follow the waste categorization for separation set forth in the Ecological Solid Waste Management Act of 2000 (RA 9003). These categories are biodegradable waste, recyclable waste, residual waste, and special waste. Biodegradable waste is organic waste that undergoes biological degradation under controlled conditions and can then be converted into compost. On the other hand, recyclable wastes are collected from the waste stream and converted to appropriate beneficial uses. Residual wastes are solid wastes that are neither compostable nor recyclable and that must be disposed of through long-term disposal or sanitary landfilling. Special wastes are hazardous wastes generated by domestic households [14]. In addition, the proposed infrastructure that is needed and targets for MSWM to be implemented within the next 25 years [15] include the expansion of collection areas, the introduction of landfill gas recovery [13], and incineration [16]. Recycling and composting at the barangay (the smallest political unit in the Philippines) or village level will also play an important role in achieving the target waste diversion rates. Therefore, villages without material recovery facilities (MRFs) are encouraged to form market linkages with the nearest and most suitable waste product storage sites to meet their collection and recovery needs [13].

The proposed system relies heavily on the success of source-separated collections, which are as yet not widely practiced in the Philippines. In addition, there are limited studies on the impact of the proposed MSWM system on cities and municipalities. The maximum capacity of each treatment facility and a market for valuable outputs (e.g., recycled materials, compost, and energy generated from waste) is necessary for the proposed MSWM system to function sustainably in the city. Hence, qualitative and quantitative information on current and future MSWM systems will provide valuable supporting resources for policy formulation and appropriate waste treatment, and for the development of disposal facilities in Davao City and other areas with similar conditions.

Material flow analysis (MFA) and life cycle assessment (LCA) are often used to analyze the environmental burdens that need to be considered as part of the decision-making process to better understand current and proposed MSWM systems. In recent studies, LCA has been used to assess the environmental impacts of existing and potential improvements to MSWM systems [2,3]. LCA has also been used to compare different MSWM scenarios regarding mixed MSW $[17,18]$ and individual waste fractions $[8,19]$.

Furthermore, several models have been developed by which to design the ideal MSWM system and waste management system solutions, based on various waste management technologies, most of which are oriented toward economic optimization [4,20-25]. Some have also taken into consideration the GHG emissions of MSWM systems, the limitations of the current treatment technologies, and the demand for MSWM by-products in the respective study area (see Table S1 in the Supporting Information). However, despite the realities of separation, as presented in some system assessment models, most optimization models generally set the waste separation rate at $100 \%$. There is also limited literature published that discusses the impact of local waste separation categories and separation success rates on the proposed systems' functioning. This is especially significant when adding new technologies that require a prescribed amount and quality of waste inputs, such as in the case of incineration.

This study attempts to integrate the proposed treatment/disposal options, taking into account the waste separation categories, local demand for the useful outputs of MSWM, 
and the minimization of GHG emissions in the Philippines. Hence, this study aims to assess whether adopting the proposed management system in 2027 will reduce GHG emissions compared to the baseline MSWM system, set in 2017. In addition, the performance of the future system, assuming varying degrees of success in implementing the source separation and collection system, will be evaluated. Therefore, LCA and linear programming (LP) optimization are utilized to determine the ideal MSW treatment network for Davao City. Furthermore, a stepwise approach was used to (1) compare the current MSWM system with future scenarios, (2) examine the environmental performance of future scenarios based on different management priorities, and (3) establish a greener future system for Davao City by changing the existing waste separation categories.

\section{Materials and Methods}

\subsection{Study Area}

Davao City is the third-largest city in the Philippines and the most populous city in Mindanao. The total waste generation in the city in 2017 was 991 TPD, 80\% of which was from residential sources, followed by public markets at $7 \%$. The per capita waste generation from all sources was $0.58 \mathrm{~kg}$. As shown in Table 1, biodegradable and recyclable components account for $50 \%$ and $18 \%$ of total waste generation, respectively, while residual and special waste account for $29 \%$ and $2 \%$, respectively [13].

Table 1. The physical composition of MSW in Davao City.

\begin{tabular}{|c|c|c|c|c|c|}
\hline \multirow{2}{*}{ Material Composition } & \multirow{2}{*}{$\begin{array}{c}\text { Composition } \\
(\%)\end{array}$} & \multicolumn{4}{|c|}{ MSW Separation Categorization (\%) } \\
\hline & & Biodegradable & Recyclable & Residual & Special \\
\hline Food & 43.40 & 43.40 & & & \\
\hline Yard, wood & 6.68 & 6.68 & & & \\
\hline Glass, ceramic, stone & 4.26 & & 3.51 & 0.75 & \\
\hline Steel & 2.52 & & 2.52 & & \\
\hline Metals Aluminum & 0.29 & & 0.29 & & \\
\hline Paper & 17.29 & & 6.88 & 10.41 & \\
\hline Plastic, rubber & 20.14 & & 5.22 & 14.92 & \\
\hline Textile & 3.11 & & & 3.11 & \\
\hline Others & 2.31 & & & & 2.31 \\
\hline Total & 100.00 & 50.08 & 18.42 & 29.19 & 2.31 \\
\hline
\end{tabular}

By 2027, total waste generation in the city is projected to reach 1209 TPD, or 441 kilotons (kt), of MSW annually. The 10-year ESWMP assumes that the waste composition in 2027 will be consistent with that in 2017.

\subsection{Methodology}

MFA and LCA were used to quantify MSW flows and estimate the GHG emissions for MSWM systems in both current and future scenarios. The LCA results were then used to identify the emission factors per ton of waste in processes associated with this study. Finally, these values were used as input data for the LP optimization model, to identify potential improvements or solutions for the 2027 scenario.

\subsubsection{MFA}

Field visits and interviews were conducted from February 2020 to March 2020, to collect primary and secondary data for the study area. Following these initial studies, a city-level waste flow analysis was conducted to establish a baseline for Business-as-Usual (BAU) practices and future MSW flow upon implementing the local waste diversion plan.

\subsubsection{LCA}

Following the implementation of MFA, LCA is used as an assessment tool. The technical framework of the LCA methodology is as outlined here. This part of the study 
aims to assess GHG emissions from the existing and future MSWM systems in Davao City. The current research has been limited to assessing the emissions of $\mathrm{CO}_{2}, \mathrm{CH}_{4}$, and $\mathrm{N}_{2} \mathrm{O}$ from the studied MSWM systems.

The relevant processes for the current and future scenarios will be included in the MSW management system boundary. However, as shown in Figure 1, the collection and transportation of MSW from the source in each scenario are not included in the system boundary. Apart from the direct processes related to the waste management system, other related processes involved in the waste management system are included. Furthermore, a system expansion or an avoided burden approach (as employed by Nakatani, 2014 [26]) is used to assess whether products recovered from the MSWM system can be used as a substitute for products from virgin resources in other systems.

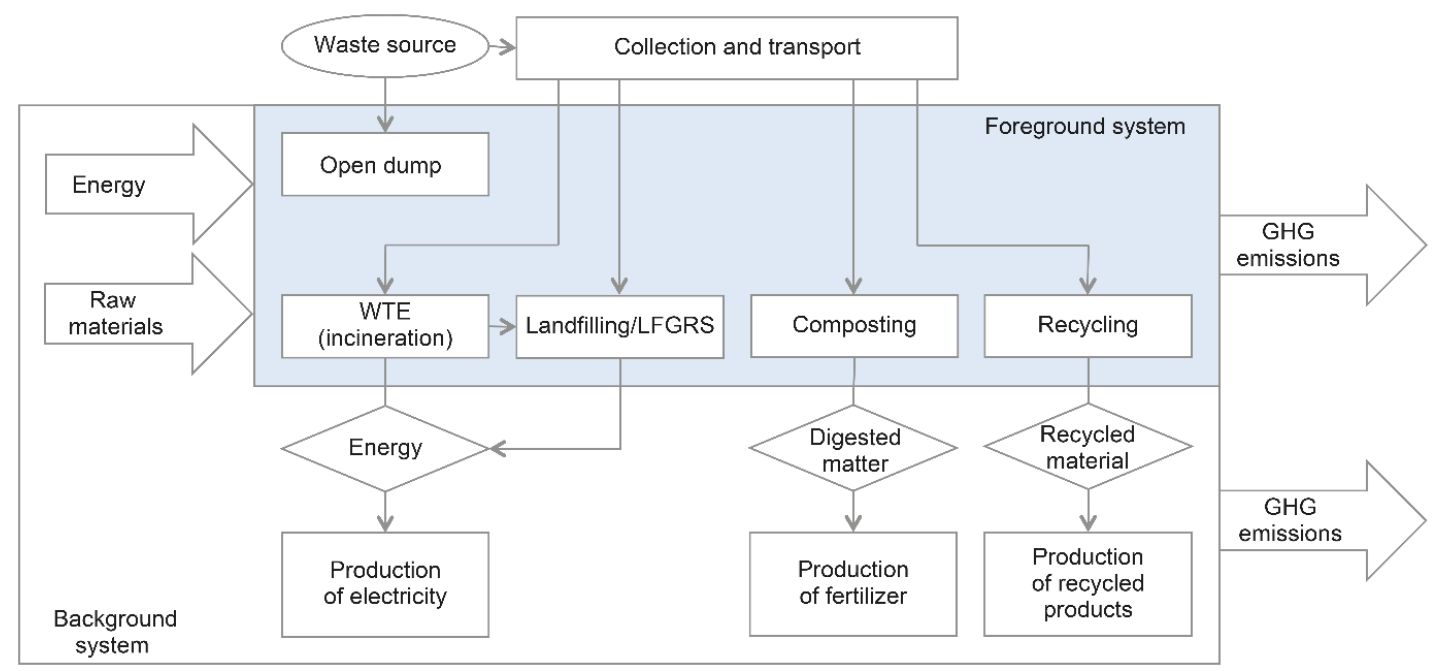

Figure 1. The system boundary of LCA in this study.

This phase was undertaken to compile the input and output data associated with all relevant processes included in the system boundary onto worksheets in Microsoft Excel. Emission factors related to current and future MSW treatment options were calculated using local government information and emission factors drawn from various databases and the literature. Emission factors for open dumping, landfilling, and LFGRS were calculated according to Manfredi et al. (2009) [27], using the Intergovernmental Panel on Climate Change (IPCC) default values for methane emissions and diesel and electricity demand. Emission factors for material recycling were obtained from the work of Friedrich and Trois (2013) [28]. Fossil carbon dioxide emissions from incineration systems were calculated using the lower heating values reported by Dong et al. (2013) [3] and diesel and electricity requirements reported by Astrup et al. (2009) [29]. In the case of composting, the compost produced can be used as a low-quality fertilizer (or soil conditioner). Diesel fuel and electricity requirements for composting were calculated using the values reported by Boldrin et al. (2009) [30].

The emission factors for combined conventional power generation in the Mindanao grid were collected from the Department of Environment and Natural Resources $(0.468 \mathrm{~kg}$ $\mathrm{CO}_{2}$-eq $/ \mathrm{kWh}$ ) and were used to calculate the avoided emissions from recovered electricity with waste-to-energy facilities. In addition, the emissions related to diesel combustion were calculated using emission factors reported by Fruergaard et al. (2009) [31].

The GHG emissions calculated in this study are expressed in terms of global warming potential (GWP). The equivalency factors of global warming were obtained from the IPCC [32]. For example, $\mathrm{CO}_{2}$ has a GWP of 1 , whereas $\mathrm{CH}_{4}$ and $\mathrm{N}_{2} \mathrm{O}$ have GWPs of 28 and 265 , respectively. 


\subsubsection{LP Optimization}

In this study, an LP model was applied to project the structure of the MSWM system in Davao City in 2027, comprising waste treatment technologies widely implemented in many developing countries. We considered four performance indicators in line with the goals of the 10-year ESWMP for Davao City [13], i.e., environmental (GHG emissions and the amount of landfill waste), economic (revenue), and energy (energy produced from waste) indicators. Moreover, we considered the potential demand for the products recovered from waste as the upper limit constraint, and their sales prices were estimated based on the City Government of Davao (2017) [13] and Asian Development Bank (2013) [33] (see Figure S1 in the Supporting Information).

The objective functions applied in the model correspond to the scenarios analyzed in this part of the study. This includes minimizing the GHG emissions of the system, maximizing the revenue from the system, and minimizing the MSW allocated for final disposal at the sanitary landfill.

System GHG emissions. This refers to the GHG emission of the system ( $\mathrm{CCO}_{2}$-eq/year) shown in Equation (1) as GWP. Here, $j$ is the type of treatment facility, $i$ is the type of waste, $q_{i j}$ is the quantity of waste $i$ (t/year) assigned to treatment process $j$, and $\mathrm{emf}_{i j}$ is the emission factor of waste $i$ for treatment $j\left(\mathrm{t} \mathrm{CO}_{2}-\mathrm{eq} / \mathrm{t}\right)$.

$$
\mathrm{GWP}=\sum_{j} \sum_{i} q_{i j} \cdot \mathrm{emf}_{i j}
$$

Energy generated by the system. This refers to the cumulative energy generated by the waste incineration plant and landfill gas recovery system. In Equation (2), ERP $\mathrm{E}_{i j}$ refers to the energy recoverable from waste, $i$, in treatment $j$.

$$
\text { Energy }=\sum_{j} \sum_{i} q_{i j} \cdot \mathrm{ERP}_{i j}
$$

Revenue generated by the system. Revenue shall be limited to the sale of recovered MSWM products, $k$, such as compost, electricity, and recyclables. Waste disposal costs that are paid to treatment facilities, i.e., revenue from the facilities other than the sales of recovered products, are not considered because we focus on the quantity of the useful outputs that can be obtained from waste in this study.

$$
\text { Revenue }=\sum_{k} q_{k} \cdot \mathrm{PRICE}_{k}
$$

Furthermore, the model is subject to the constraints described below.

Mass balance constraints. This refers to the amount of waste to be transported to the disposal or treatment process, $j$. In Equation (4), $q_{i j}$ refers to the amount of waste, $i . q_{i j}$ refers to the amount of waste, $i,(t / y)$ allocated to the treatment facility.

$$
\sum_{i} q_{i}=\sum_{j} \sum_{i} q_{i j}
$$

Maximum capacity constraints. The amount of waste resource for each facility should be less than or equal to the maximum allowable amount for that facility. In Equation (5), $Z_{j}$ refers to the planned capacity (units/y) of facility $j$.

$$
\sum_{i} q_{i j} \leq Z_{j}
$$

Waste allocation constraints. Each type of waste should be treated only in an appropriate treatment facility. In Equation (6), $a_{i j}$ refers to the waste availability coefficient (\%) of 
waste $i$ in treatment process $j$. The waste composition, following the conditions of waste categorization under RA 9003, governs this variable.

$$
q_{j} \leq a_{i j} \cdot \sum_{i} q_{i}
$$

Recovered product demand. The production rates of electricity, compost, and recycling materials must fulfill the product demands. The demand for compost products should be dictated by the total agricultural area of the study area, where $5 \mathrm{t}$ /ha of compost will be allocated. The electricity demand shall be subject to the design generation capacity of the WTE plant, as defined in the local policy. On the other hand, the demand for recycled materials shall be subject to the capacity of the material recovery/recycling facilities in the study area. In Equation (7), $q_{k}$ refers to the production rate of product $k$ (units $/ y$ ), while $d_{k}$ refers to the demand for product $k$ (units/y).

$$
q_{k} \leq d_{k}
$$

Non-negativity constraints. This constraint means that only positive amounts of MSW will be considered in the solution.

$$
q_{i j} \geq 0
$$

The model formulated in this study has been developed and implemented using Excel Solver.

\subsection{Description of Alternative Scenarios}

This study utilized a stepwise approach to understand the impacts of change on the waste situation in Davao City and identify possible improvements. Various scenarios were proposed and evaluated, as follows.

2.3.1. Examining the Effectiveness of Additional Treatment and Disposal Methods, and Source-Separated Collection

Two scenarios are considered to establish whether a local waste diversion plan can reduce GHG emissions from the existing MSWM system.

Scenario 1. This scenario is defined as the baseline scenario of the MSWM system in 2017. Source-separated collection practices are not considered, and the waste management options are composting, recycling, and landfilling. Due to limited collection compliance, a significant fraction of the waste generated is disposed of by open dumping. Losses in existing collection areas are also assumed to be openly dumped.

Scenario 2. By 2027, source-separated collection will be considered to occur according to the local waste diversion plan. The municipal collection covers all barangays except one because of poor road conditions in the area. Therefore, it is assumed that waste in this excluded barangay is disposed of via open dumping. Waste management options include composting, recycling, landfilling (including gas recovery), incineration, and household hazardous-waste storage.

\subsubsection{Establishing an Environmentally Friendly Future MSWM System}

In order to improve the MSWM system in Davao City, a 10-year ESWMP was prepared for the period 2018-2027 [13]. The goals outlined in the plan include maximizing the generation of power from waste, extending the life of the sanitary landfill, and minimizing the GHG emissions of the MSWM system. In this section, we evaluate how choosing an optimization goal that corresponds to the goals of the local waste management plan can change the environmental performance of alternative scenarios. The same MSW categories and quantities generated, as in Scenario 2, are considered. The following three scenarios are subject to the upper limit constraints of disposal/treatment options and the estimated demand for valuable outputs in the study area.

Scenario 3. The 2027 system is optimized to minimize GHG emissions. 
Scenario 4. The sale of useful outputs is maximized to generate the most revenue. As a result, the power generation capacity of WTE facilities and the recycling and composting processing capacity can be maximized.

Scenario 5. Minimizing landfill waste is a priority when allocating waste to disposal and treatment facilities.

\subsubsection{Examining the Effectiveness of Waste Separation}

Changes in the local recycling market, such as market standards for recyclable materials, can result in differences in the ratio of recyclable to residual fractions of the waste stream. In this part, the impact of the increase in the recyclable fraction on the performance of the MSWM systems, as described in Scenarios 3 to 5, will be discussed. The same amount of MSW is assumed to be generated as in Scenario 2, taking into account the upper limit constraints of the waste treatment facilities and the demand for useful outputs. Scenarios 3 to 5 are optimized by turning off the upper limit constraints for the recyclable fraction.

\subsection{Sensitivity Analysis}

The performance of the future MSWM system may be greatly affected by various factors, including the performance of the separation rate in the segregated collection. Hence, a sensitivity analysis was conducted on the change in the separation rate of biodegradable and recyclable wastes in the 2027 system, considering the upper limits of various treatment methods in the study area. In addition, we investigated the sensitivity in GHG emissions of the 2027 scenario to the amount of plastic waste generation, which was considered to be one of the most influential factors on GHG emissions from waste incineration and on the avoided emissions from recycling.

\section{Results and Discussion}

\subsection{MFA of Current and Future Scenarios}

\subsubsection{MFA of the MSWM System in 2017}

In the BAU scenario, municipal collection services are provided to only $65 \%$ of the population, most of whom reside in the city's relatively flat and densely populated areas. The estimated waste generation within the collection area was 835 TPD in 2017 [13], of which only 611 TPD (Figure 2) was collected by the local government [34]. The uncollected waste and losses in the collection area are estimated at 156 TPD and 188 TPD, respectively. Out of 182 barangays in the city, there are four barangays with functioning MRFs, of which two barangays have vermiculture composting facilities. The current processing capacity of the MRFs is 1 TPD [15], mainly processing organic waste.

The material flow in the BAU scenario is shown in Figure 3. The collection activities by the private waste sector can be further divided into formal and informal sectors. The material recovery system in the city is mainly established by the informal waste sector (IWS), which supplies the recovered waste as raw materials to the formal private sector. Due to the limited available data, direct flows from non-residential sources to recycling facilities exist but are excluded from this study. The IWS includes roving waste buyers, street collectors, the municipal collection crew, and waste pickers at landfills. The estimated amount of waste recovered for recycling by IWS is about 50 TPD [15,16], 15 TPD of which is contributed by the municipal collection crew. This total value excludes the yield of waste pickers at landfills. As of August 2017, there are 44 registered junk shops in the city, with an estimated total yield of 73 TPD [13]. According to a JICA survey (2008) [35], the recyclables collected in the city comprised $29.1 \%$ plastic, $28.5 \%$ paper, $25.0 \%$ metal, $17.0 \%$ glass, and $0.4 \%$ other materials. These recyclables were then consolidated in waste product storage facilities and sold to their primary buyers, such as plastic recycling plants, steel mills, and paper mills. 


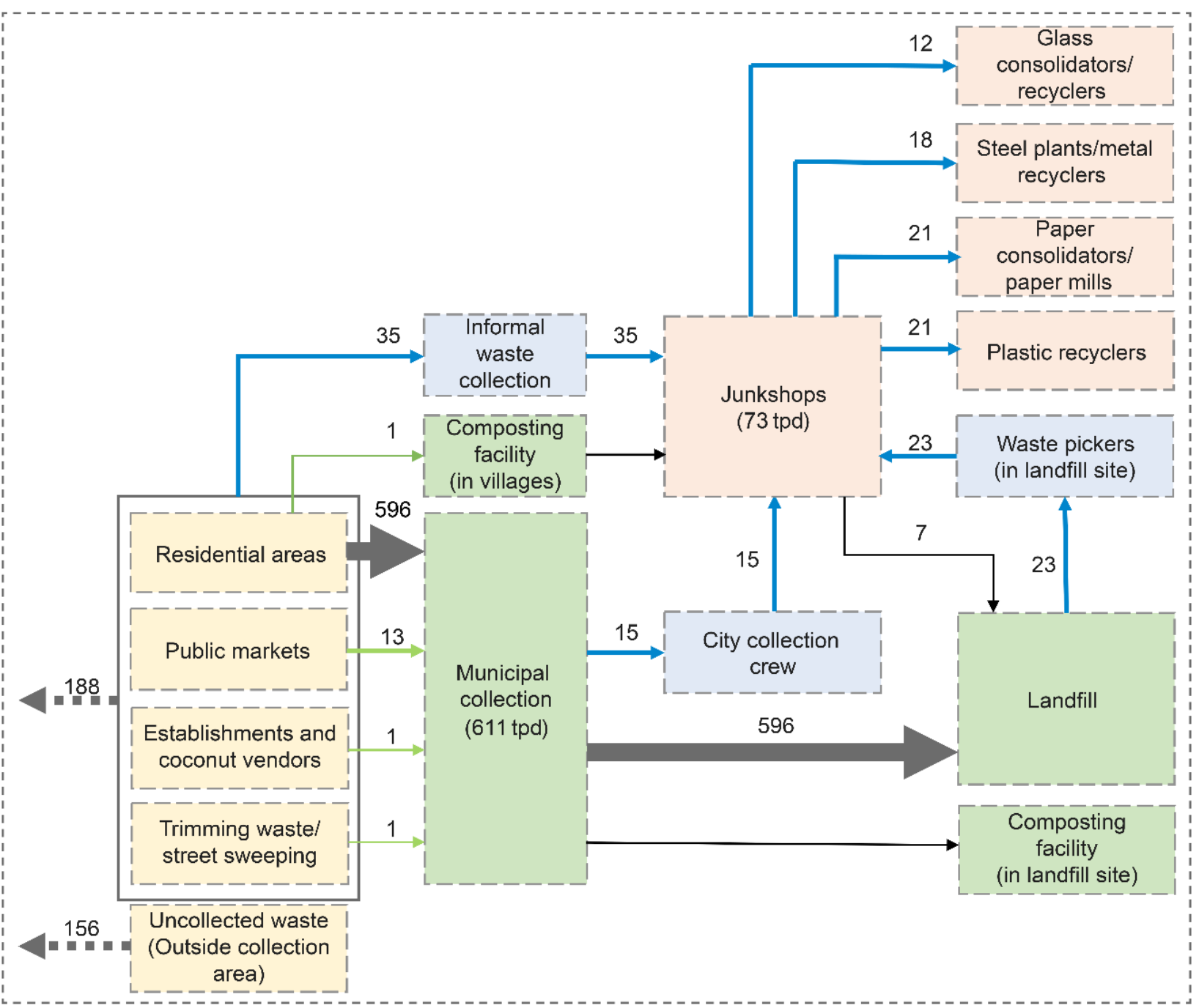

Figure 2. Current status of MSWM in Davao City, Philippines (tons/day: TPD).

There is only one sanitary landfill (SLF) in Davao City, located in Barangay New Carmen. It covers an area of 3.8 ha and has a capacity of 2.85 million $\mathrm{m}^{3}$ [36]. The landfill started operation in 2010, and the remaining service life of the landfill is estimated to be about 6 years (after the publication of this report in 2018) [34]. The landfill received an estimated amount of 596 TPD in 2017. The landfill site has a composting facility with three rotary composters, which process 3.5 tons per month (TPM) of biodegradable waste to produce 1.5 TPM of compost. The compost generated is used for greening and beautification programs in the city and is distributed free of charge to institutions and small farms upon request [13]. There are also about 200 waste pickers at the landfill. Data on the breakdown of waste recovered by the waste pickers were collected through the receipts used by them to receive payment from buyers. Twenty-two receipts were collected by the researchers. The results showed that the 22 waste pickers collected a total of $3054 \mathrm{~kg}$ of waste materials (an average of $139 \mathrm{~kg}$ per person), which consisted of plastics (42.22\%), metals (28.16\%), paper and cardboard $(24.82 \%)$, glass $(4.14 \%)$, batteries $(0.59 \%)$, and coconut shells $(0.07 \%)$. 


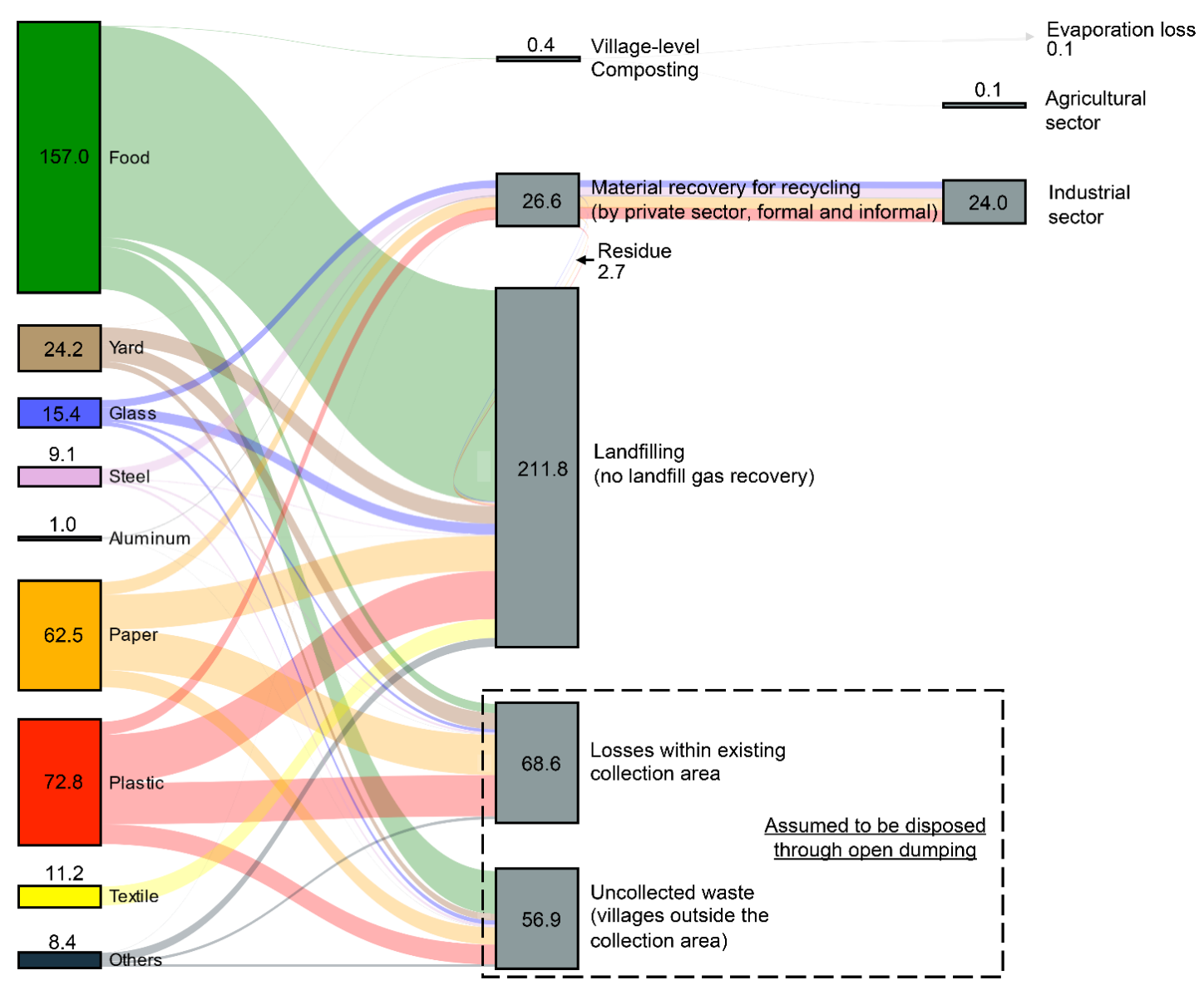

Figure 3. Material flow in the BAU scenario (2017) (unit: kt/yr).

\subsubsection{MFA of the MSWM System in 2027}

Figure 4 shows the waste flow in the city, according to material composition, for the proposed MSWM system based on the local waste diversion plan. The outline of the proposed MSWM system is shown in Figures S2 and S3 in the Supporting Information.

One of the fundamental changes in the proposed future MSWM system is that the Davao City Environment and Natural Resources Office (CENRO) aims to collect $100 \%$ of MSW by 2025 [36]. They intend to implement a segregated collection and transport system by establishing an MRF in each village or a cluster of villages to receive, sort, process, and store compostable and recyclable materials. The following calculations assume that all villages except Barangay Gumitan, which has poor road conditions, will have a village-level MRF capable of receiving and sorting $100 \%$ of the waste generated in the village. By 2027, a 50-TPD composting facility and an 18-TPD centralized MRF will also be established. The local waste diversion plan also acknowledges the activities of IWS by allocating recyclable waste diversion by a scavenging crew.

Davao also proposes to operate the Philippines' first WTE facility in $2022[34,36]$, which is projected to have a capacity of 600 TPD and to generate 9.7 MW of electricity, or $74,688 \mathrm{MWh} / \mathrm{yr}$ [16]. This amount corresponds to about $2 \%$ of the demand forecast of the Davao Light and Power Company for 2027 [37]. The city has also acquired land for establishing new sanitary landfills, with an estimated capacity of 3 million tons [34]. In addition, according to the local plan, a private developer has expressed interest in setting up a gas-to-energy project at the New Carmen disposal facility [13]. However, due to the limited information available on this project, details such as the power generation capacity of the proposed project are based on the Payatas disposal facility in Quezon City, which is referenced in the 10-year ESWMP of Davao City (2018-2027) [13]. 


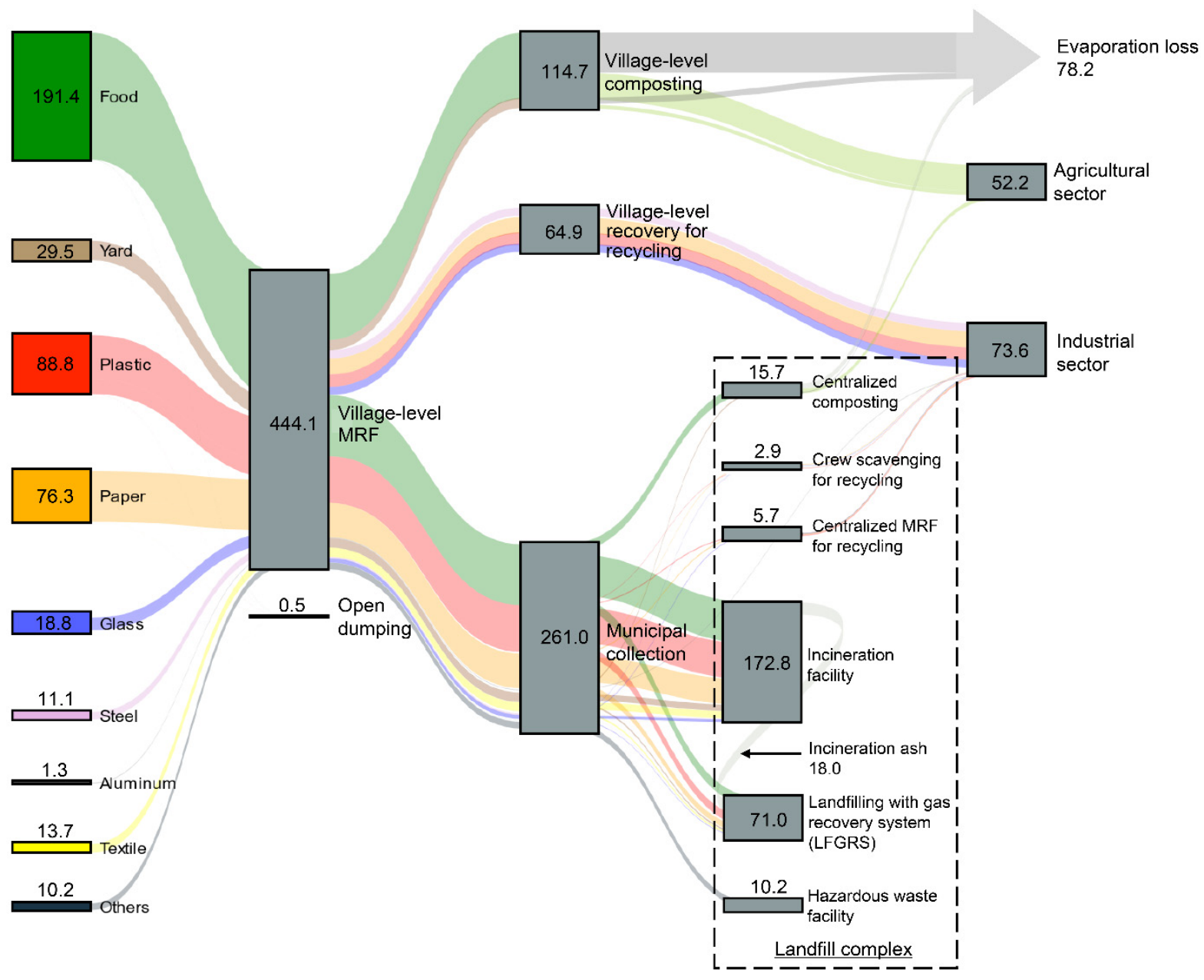

Figure 4. Material flow of the future scenario (2027) (unit: kt/yr).

\subsection{Comparison of Current and Future Scenarios}

In the BAU scenario, $58.6 \%$ of the waste generated was allocated to landfills, $15.7 \%$ was uncollected, $6.6 \%$ was recovered for recycling by the private formal and informal sectors, and $0.1 \%$ was composted. Losses within the existing collection area accounted for $19 \%$, and there was no energy production activity from MSW. The BAU scenario generated an estimated emission amount of $271 \mathrm{kt} \mathrm{CO}_{2}$-eq/yr (Figure 5). In addition to the emissions shown in Figure 5, diesel consumption for waste collection leads to an estimated $1.2{\mathrm{kt} \mathrm{CO}_{2}-}^{-}$ eq/yr of GHG emission, which is much smaller than the emissions from landfilling and open dumping. The most significant contributor to GHG emissions in this scenario is the release of methane from landfills and open dumps, due to the degradation of organic waste. It must be noted that the current landfill system is not equipped with a gas collection system.

Future scenarios were designed to anticipate trade-offs between the separation process and additional MSW treatment/disposal options. Based on the local waste diversion plan, $39.2 \%$ of the total waste will be allocated to incineration, $29.6 \%$ to composting, $12.2 \%$ to LFGRS, and $2.3 \%$ to hazardous waste storage; only $0.1 \%$ will remain uncollected. Therefore, in the 2027 scenario, the system is expected to emit $73 \mathrm{kt} \mathrm{CO}_{2}$-eq per year, with the incinerated plastic fraction of the residual waste being the main contributor to emissions (Figure 6). Taking this into account, the system's emissions will decrease from $0.75 \mathrm{tCO}_{2}$-eq per ton of MSW in the 2017 scenario to $0.17 \mathrm{t} \mathrm{CO}_{2}$-eq per ton of MSW. 


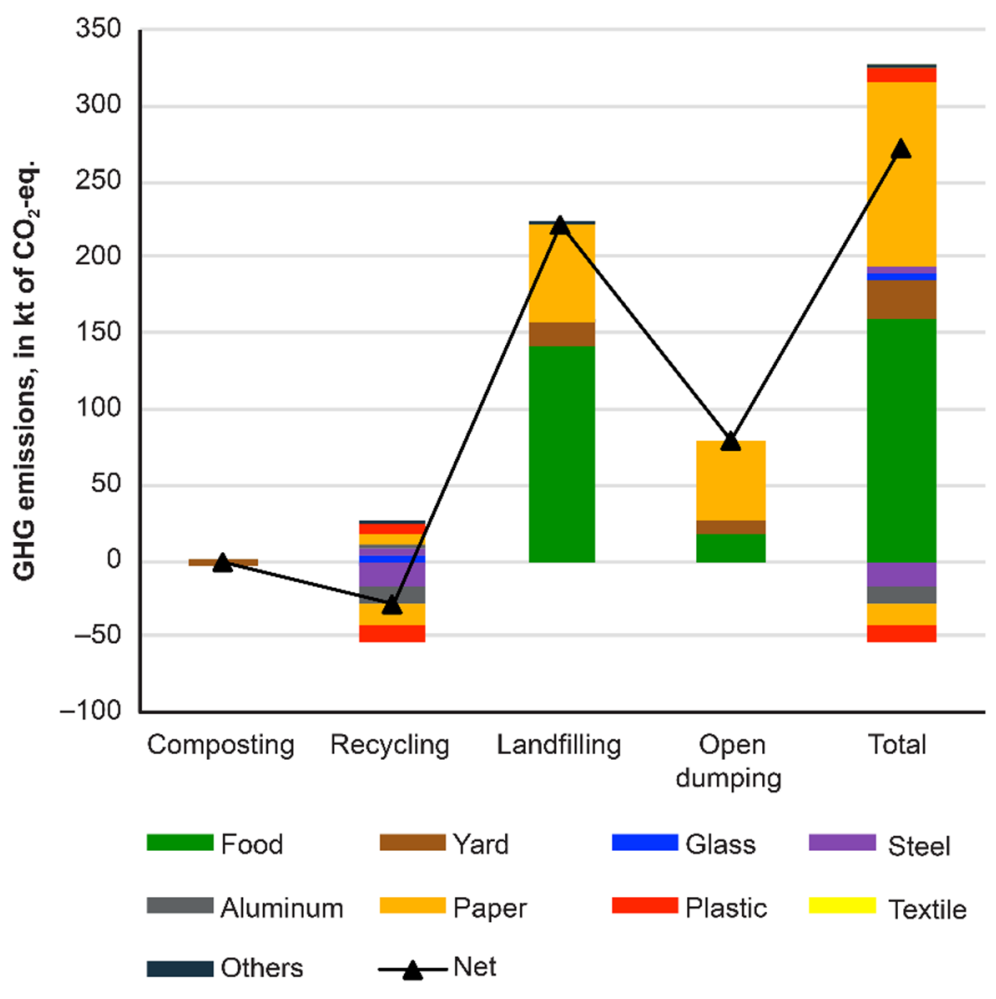

Figure 5. Estimated annual GHG emissions in the 2017 scenario.

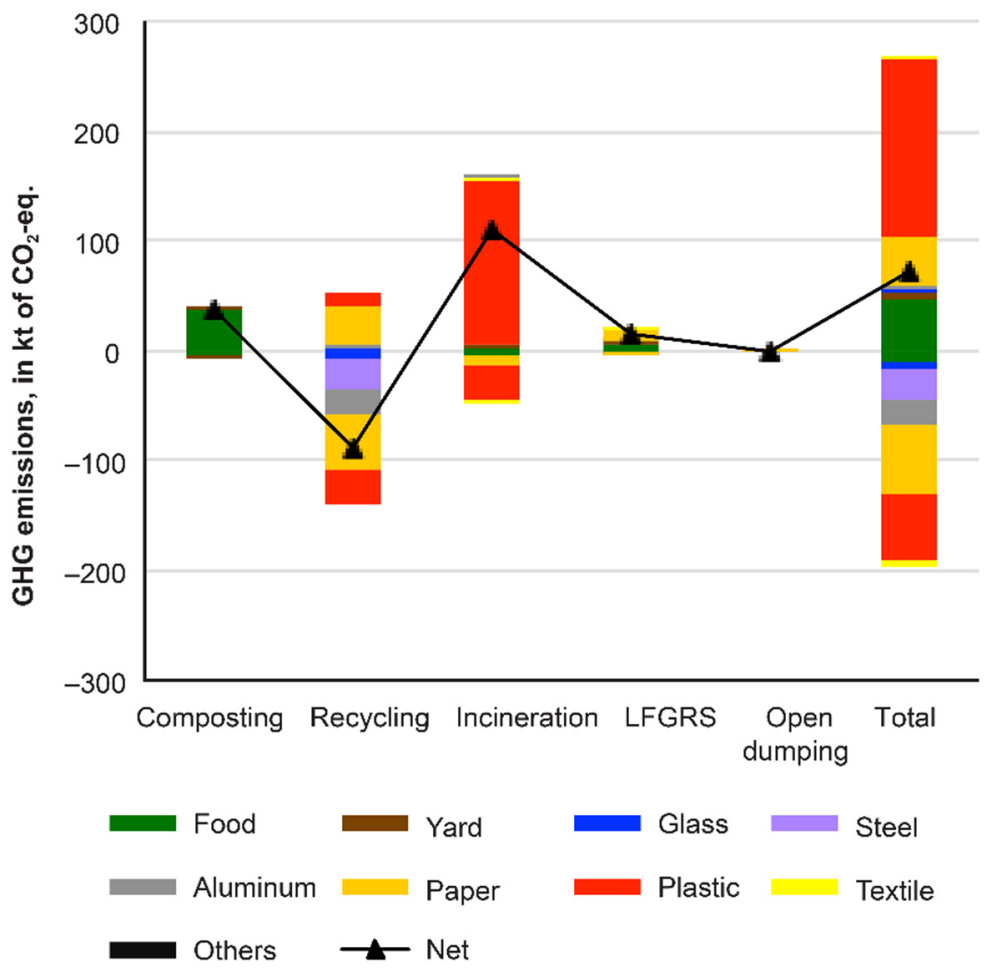

Figure 6. Estimated annual GHG emissions of the 2027 scenario.

However, in the local plan for the 2027 scenario, the challenge is that the maximum power generation of the incineration plant will be reached before the maximum annual throughput of MSW is reached. Furthermore, the upper limit of the local demand for recyclable materials has been estimated. As a result, it is anticipated that a significant amount of MSW will be diverted from the recycling and incineration processes to the sanitary landfill. 
Such a change in the allocation of MSW will result in changes in the expected performance of the MSWM system. Here, the net GHG emissions from incineration and landfilling become 46 and $60 \mathrm{kt} \mathrm{CO}$-eq/yr, respectively, and the avoided emissions from recycling and composting become $-45 \mathrm{kt} \mathrm{CO}_{2}$-eq/yr. Consequently, the volume of system GHG emissions can decrease to $60 \mathrm{kt} \mathrm{CO}_{2}$-eq/yr.

\subsection{Sensitivity Analysis}

The performance of the 2027 MSWM system mentioned earlier is greatly affected by the performance of the separation rate in the segregated collection. As a result of the sensitivity analysis considering the upper limits of various treatment methods in the study area, the target separation rates in the 2027 local plan will be $59 \%$ for biodegradable wastes and $91 \%$ for recyclable wastes.

\subsubsection{Sensitivity Analysis of Landfill Waste to Separation Rate}

One of the major impacts of the change in separation rate can be seen in the annual amount of landfill waste. It is assumed that the future landfill facility will have a capacity of 3 million tons and will be operational from 2022 to 2045. Therefore, to achieve sustainable waste management during this 24-year period, it is assumed that the annual amount of landfill waste will not exceed 125 kilotons. Therefore, to prolong the sanitary landfill's life, it is necessary to achieve adequate separation rates for both waste categories in the city (shown in Table 2 as underlined values).

Table 2. Sensitivity of landfill MSW to separation rate (kt/yr).

\begin{tabular}{|c|c|c|c|c|c|c|c|c|c|c|c|c|}
\hline & \multicolumn{11}{|c|}{ Biodegradable Waste Separation Rate } \\
\hline & & $0 \%$ & $10 \%$ & $20 \%$ & $30 \%$ & $40 \%$ & $50 \%$ & $60 \%$ & $70 \%$ & $80 \%$ & $90 \%$ & $100 \%$ \\
\hline \multirow{11}{*}{ 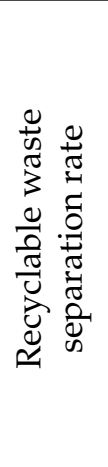 } & $0 \%$ & 258 & 242 & 226 & 210 & 194 & 178 & 163 & 148 & 133 & 119 & 105 \\
\hline & $10 \%$ & 250 & 233 & 217 & 201 & 186 & 170 & 155 & 140 & 126 & $\overline{111}$ & $\overline{98}$ \\
\hline & $20 \%$ & 240 & 224 & 208 & 193 & 177 & 162 & 147 & 132 & $\underline{118}$ & 104 & $\overline{90}$ \\
\hline & $30 \%$ & 231 & 215 & 200 & 184 & 169 & 154 & 139 & $\underline{125}$ & $\underline{110}$ & $\underline{97}$ & $\underline{83}$ \\
\hline & $40 \%$ & 222 & 206 & 191 & 175 & 160 & 145 & 131 & 117 & $\underline{103}$ & $\overline{89}$ & $\overline{76}$ \\
\hline & $50 \%$ & 213 & 197 & 182 & 167 & 152 & 137 & $\underline{123}$ & $\overline{109}$ & $\overline{95}$ & 82 & $\overline{69}$ \\
\hline & $60 \%$ & 204 & 188 & 173 & 158 & 143 & 129 & $\overline{115}$ & $\underline{101}$ & $\overline{88}$ & $\overline{75}$ & $\underline{63}$ \\
\hline & $70 \%$ & 195 & 179 & 164 & 149 & 135 & $\underline{121}$ & $\overline{107}$ & $\underline{93}$ & $\underline{80}$ & $\underline{68}$ & $\underline{56}$ \\
\hline & $80 \%$ & 185 & 170 & 155 & 140 & 126 & $\underline{112}$ & $\overline{99}$ & $\underline{86}$ & $\overline{73}$ & $\overline{61}$ & $\overline{49}$ \\
\hline & $90 \%$ & 176 & 161 & 146 & 132 & $\underline{118}$ & $\underline{104}$ & $\underline{91}$ & $\underline{78}$ & $\underline{66}$ & $\underline{54}$ & $\underline{43}$ \\
\hline & $100 \%$ & 166 & 151 & 137 & $\underline{123}$ & $\underline{109}$ & $\underline{96}$ & $\underline{83}$ & $\underline{70}$ & $\underline{58}$ & $\underline{47}$ & $\underline{36}$ \\
\hline
\end{tabular}

Note: Underlined values $\leq 125 \mathrm{kt}$ MSW/yr; estimated upper limit of local demand for recyclables at $74 \%$.

This problem is exacerbated by the limited estimated demand for recyclable materials in the study area, requiring higher separation rates for biodegradable waste. In addition, the local waste diversion plan still relies heavily on the support of a network of formal and informal private waste sectors, suggesting the need to promote the capacity-building of these establishments (e.g., waste product storage facilities).

\subsubsection{Sensitivity Analysis of System GHG Emissions to Separation Rate}

Increasing the separation rate of biodegradable and recyclable wastes will reduce the GHG emissions of the system. However, as shown in Figure 7, a significant decrease in emissions is expected with increasing the biodegradable waste separation rate compared to that of recyclable waste. 


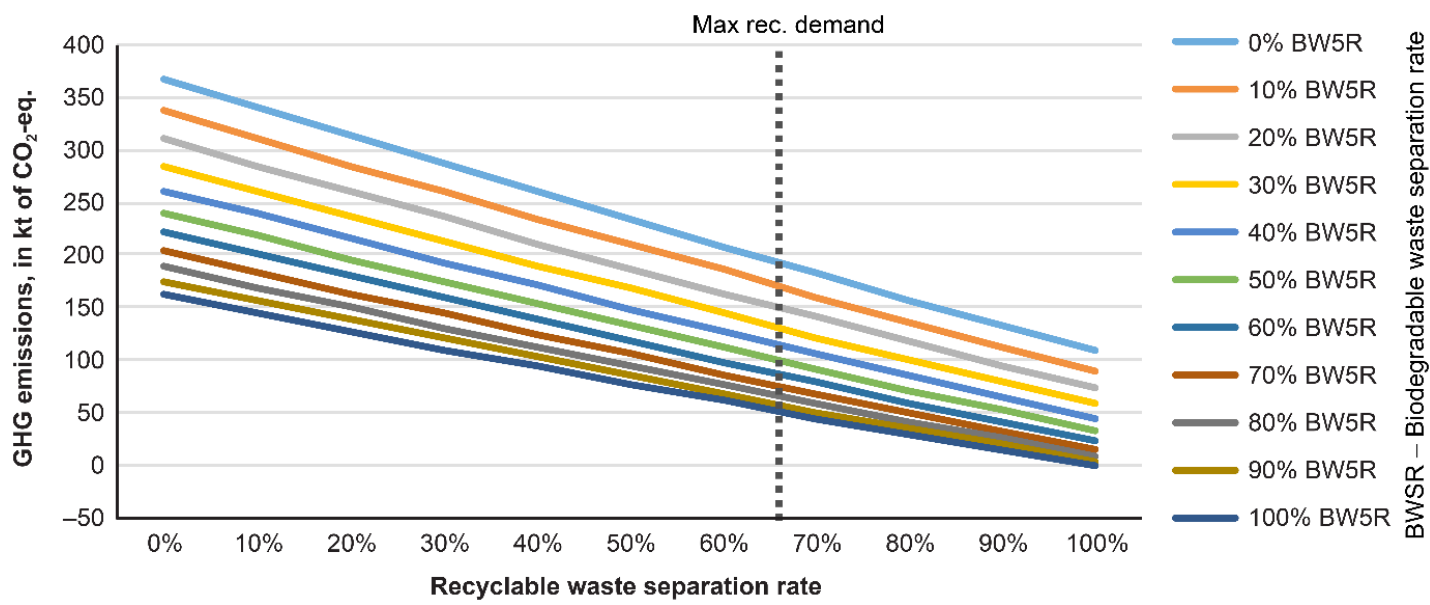

Figure 7. Sensitivity of system's annual GHG emissions to separation rate.

GHG emissions in the 2027 scenario will be heavily affected by the relationship between separation rates and the management of lower calorific value (LCV) of MSW for incineration. Without an efficient source separation of biodegradable and recyclable waste fractions, the maximum power generation of the incineration facility will be reached before the annual amount of processed MSW is capped, leading to an increase in landfill waste. On the other hand, one of the main influencing factors for the high LCV of incinerated MSW is the high percentage of residual plastic waste that is not affected by the improved separation rate. Hence, improving the separation system according to the individual material composition will benefit future MSWM systems, which will be discussed in the following section.

\subsubsection{Sensitivity Analysis of System GHG Emissions to Plastic Waste Generation}

When the amount of plastic waste generation changes in the range of $\pm 50 \%$, the net GHG emission from incineration in the 2027 scenario, considering the upper limit constraint of the facilities to be $46 \mathrm{kt} \mathrm{CO}_{2}-\mathrm{eq} / \mathrm{yr}$, is expected to proportionally vary between 34 and $51 \mathrm{kt} \mathrm{CO}_{2}$-eq/yr. Similarly, the net GHG emission from landfilling is expected to vary between 16 and $103 \mathrm{kt} \mathrm{CO}_{2}$-eq/yr, and the avoided emission from recycling and composting also varies between -49 and $-27 \mathrm{kt} \mathrm{CO}_{2}$-eq/yr. As a result, the amount of system GHG emissions can decrease to $1 \mathrm{kt} \mathrm{CO}_{2}-\mathrm{eq} / \mathrm{yr}$ when the plastic waste generation is halved, whereas it is expected to increase to $127 \mathrm{kt} \mathrm{CO}_{2}-\mathrm{eq} / \mathrm{yr}$ when the plastic waste generation increases by $50 \%$.

\subsection{LP Optimization of the 2027 Scenario}

As shown in Figure 8, the optimal solution for organic wastes, such as food and paper, is incineration to minimize the resulting system emissions. This is because the incineration of these components emits biogenic $\mathrm{CO}_{2}$, while the incineration of textiles and plastics emits fossil-fuel-derived $\mathrm{CO}_{2}$. Therefore, recyclable plastics, metals, and paper are allocated to recycling. On the other hand, residual plastics, glass, and the remaining unprocessed waste are disposed of in landfills, thus minimizing the use of composting facilities. Furthermore, the energy recovery performance of this scenario is influenced by the avoidance of the incineration of high-calorific-value wastes. Therefore, even though the system emissions are estimated to be about $-81 \mathrm{kt} \mathrm{CO}$-eq/yr, the amount of landfill waste in this scenario exceeds 125 kilotons, which may shorten the operational life of the sanitary landfill.

As shown in Figure 9, under the maximum revenue scenario, the power generation capacity of the WTE facilities and the processing capacity for recycling are maximized. As a result, the revenue from the sale of MSWM recovered products, including power generation of 82,688 MWh/year, is estimated at PHP 1.49 million. Thirty-nine percent of the total revenue will come from the recycling of plastics, followed by $37 \%$ from the sale 
of electricity. To achieve this, plastic waste will be used for incineration, increasing the LCV of incinerated waste. As a trade-off, the GHG emissions for this scenario will be $19 \mathrm{kt}$ $\mathrm{CO}_{2}$-eq/yr. Therefore, landfill waste is reduced to about $84 \mathrm{kt} / \mathrm{yr}$ in this scenario.

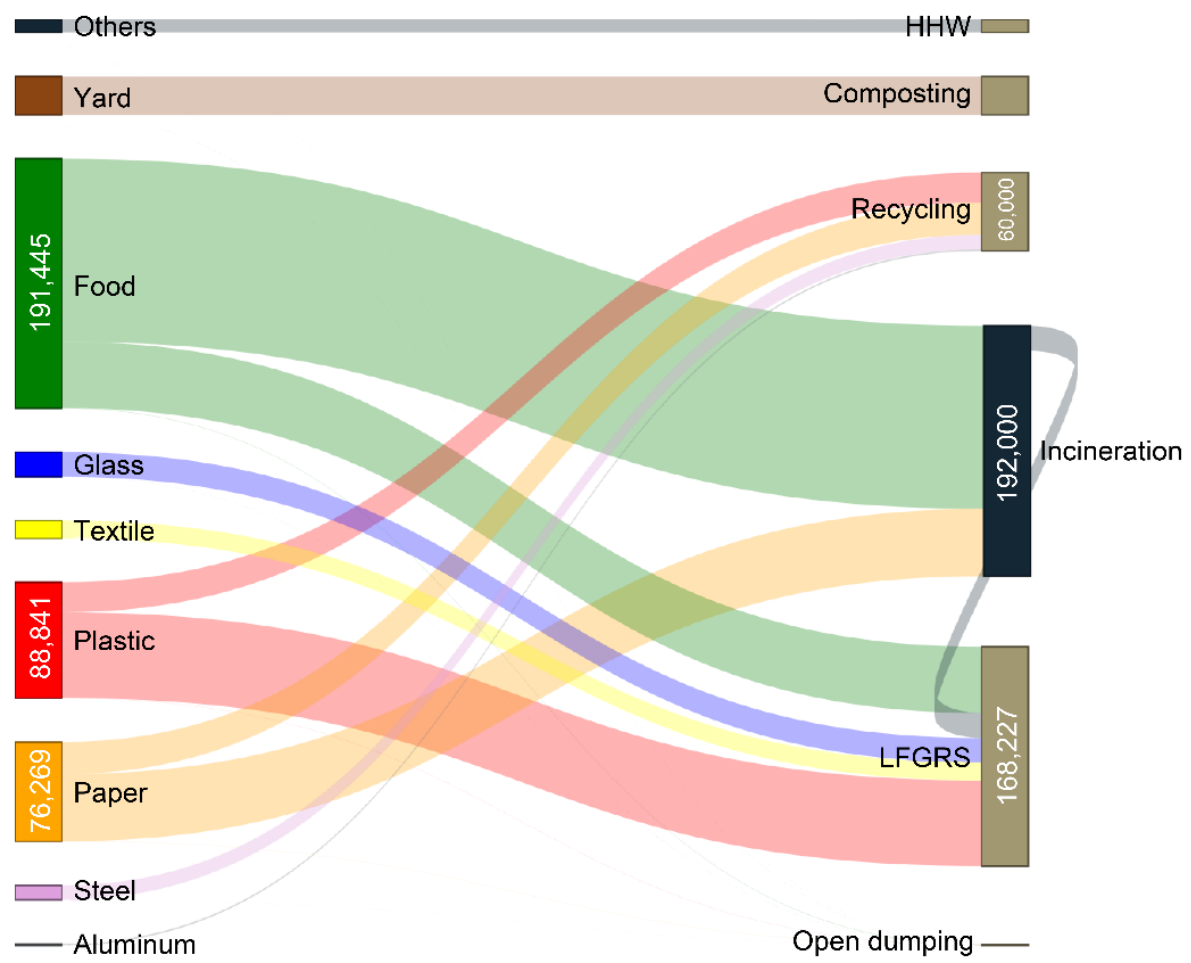

Figure 8. Optimization results: minimization of GHG emissions.

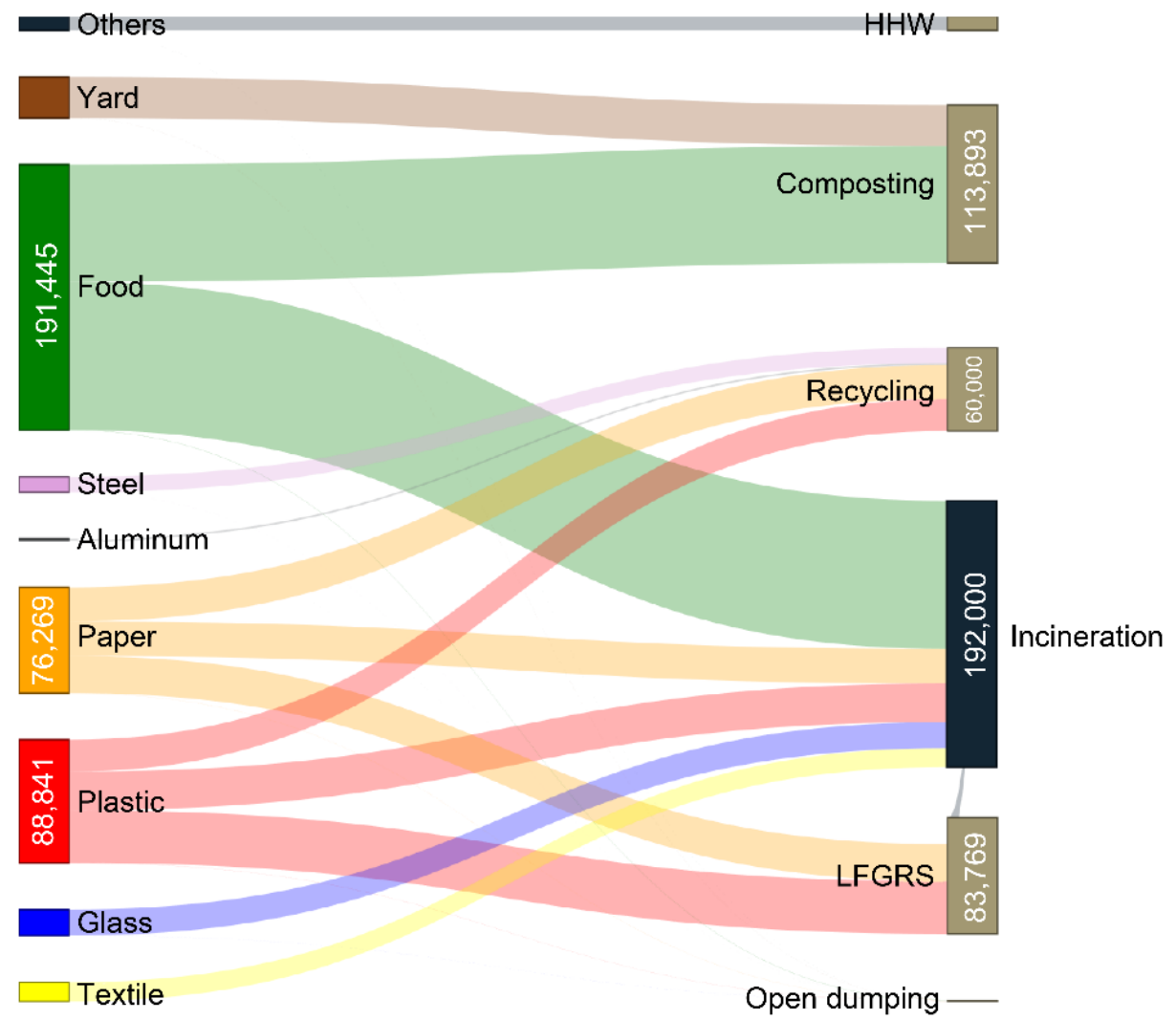

Figure 9. Optimization results: maximization of revenue. 
As shown in Figure 10, wastes with high calorific value, such as plastic and paper, are redirected to recycling activities, in line with maximizing food composting to minimize landfill waste. As a result, except for some plastic waste, all the remaining MSW would be incinerated, with an estimated emission of $-5 \mathrm{kt} \mathrm{CO}_{2}$-eq, a revenue of PHP 1.37 million, and landfill waste of $67 \mathrm{kt} / \mathrm{yr}$. This scenario involves minimal landfill gas recovery.

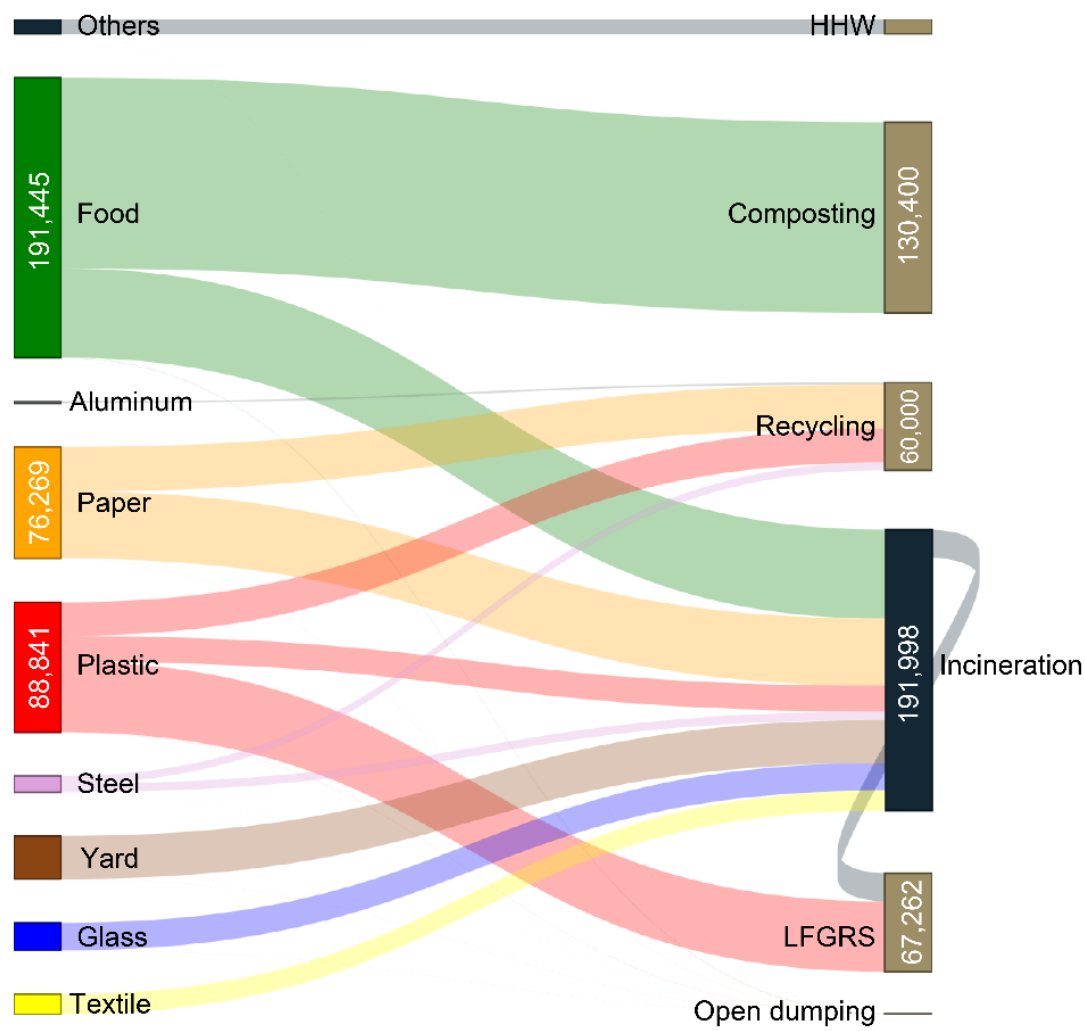

Figure 10. Optimization results: minimization of landfill waste.

\subsection{Implications of the Ratio between Recyclable and Residual Fractions of MSW}

One of the common MSW allocation procedures observed in the three scenarios is the specific allocation of plastic waste to manage the LCV for incineration. This is achieved either by maximizing recyclable plastics for recovery or by minimizing the residual plastic waste to be incinerated. This is especially noticeable in all three scenarios studied, where landfill plastic is significantly high. Therefore, the recovery or the recycling of this plastic waste with different objective functions is beneficial for revenue generation, the avoidance of emissions, and the diversion of waste from landfills.

As a result, we inputted the data into the LP model and optimized it by turning off the upper limit constraint for the recyclable fraction. This changed the distribution of the conventionally classified recyclable and residual fractions of each material (see Figure S4 in the Supporting Information). All three scenarios prioritized recycling plastic waste, causing a decrease in incinerated plastic and an increase in the incinerated MSW. This causes a decrease not only in the energy generated but also in the system emissions and landfilled waste. The results in Table 3 indicate that prioritizing the collection of waste plastics at the MRFs and expanding the local definition of recyclable plastics will bring additional environmental and economic benefits to future MSWM systems. 
Table 3. Summary of the optimization results (the upper limit constraints for the recyclable fraction are disabled).

\begin{tabular}{ccccc}
\hline Performance Indicator & Local Plan & Min GHG & Max Rev & Min LF \\
\hline \multirow{2}{*}{ GHG emissions (kt CO $-\mathrm{eq} / \mathrm{yr})$} & \multirow{2}{*}{73.5} & -88.7 & 6.1 & -19.5 \\
& & $(-80.6)$ & $(19.0)$ & $(-5.0)$ \\
Recovered energy (GWh/yr) & \multirow{2}{*}{$* 6.8^{*}$} & $(54.5)$ & 82.7 & 52.0 \\
& & 1830 & $(82.7)$ & $(67.2)$ \\
Revenue (million PHP/yr) & \multirow{2}{*}{$1631^{*}$} & $(1203)$ & $(1488)$ & $(1366)$ \\
Landfill waste (kt/yr) & \multirow{2}{*}{71.0} & 163.9 & 67.3 & 67.3 \\
& & $(168.2)$ & $(83.8)$ & $(83.8)$ \\
\hline
\end{tabular}

Note: The values in parentheses have upper limit constraints. ${ }^{*}$ Exceeds the upper limits of the incineration power generation capacity and local recyclable demand. USD $0.021=$ PHP 1.

\section{Conclusions}

In this study, an LP model was developed to optimize the future MSWM system in Davao City, Philippines. The results indicate that increased MSW treatment options, including incineration, LFGRS, composting, and MRFs, with significant source separation, will offer positive energy and environmental benefits compared to the current MSWM system.

The main emphasis regarding treatment and disposal shifts from organic waste allocation in the BAU scenario to the plastic fraction of MSW in the 2027 scenario. The mitigation of GHG emissions in future scenarios will be heavily influenced by the trade-offs between separation and incineration activities. Without significant separation to manage the LCV of MSW to be incinerated, the capacity of the incineration facility for the annual MSW that is processed will not be maximized. This results in increased landfill waste and a shortened operational life of landfills. Hence, the modified separation scheme may be more beneficial to the future MSWM system, including the specific allocation of plastic waste. This means maximizing the recovery of recyclable plastics and/or minimizing the amount of plastic to be incinerated. Furthermore, the optimization results show that treatment options dedicated to the recovery and recycling of plastics may solve the problems identified so far in the sustainable implementation of the 2027 scenario.

This model could be extended to include additional treatment and disposal options and the related investment, land procurement, and operation and maintenance costs of treatment and disposal facilities. This is because the new MSWM infrastructure, while environmentally beneficial, may be restricted by high transportation costs, local budget constraints, and land availability. Moreover, future MSW processing networks need to improve the circulation of waste materials in the selected study areas, incorporating the capacity and the limitations of other relevant industries.

Supplementary Materials: The following supporting information can be downloaded at: https:/ / www.mdpi.com/article/10.3390/su14042419/s1 [4,13,20-22,24,25,33,37], Figure S1: Process network of MSWM for 2027 in Davao City, Philippines. Figure S2: MSW collection, separation, and treatment/disposal options in the 2027 scenario. Figure S3: Supply and demand for the recovered MSWM products in the 2027 scenario. Figure S4: Changes to the material flow in optimization scenarios when the availability coefficient is disabled. Table S1: Comparison of the optimization models for solid waste management.

Author Contributions: Conceptualization, K.F.O. and J.N.; methodology, K.F.O.; validation, K.F.O., J.N. and T.F.; formal analysis, K.F.O.; investigation, K.F.O.; resources, K.F.O.; data curation, K.F.O.; writing-original draft preparation, K.F.O.; writing - review and editing, J.N.; visualization, K.F.O.; supervision, T.F.; project administration, J.N.; funding acquisition, K.F.O. All authors have read and agreed to the published version of the manuscript.

Funding: This research was funded by the Japan International Cooperation Center, through the Project for Human Resource Development Scholarship, by Japanese Grant Aid (JDS B0012019PHL007) for the graduate studies of Kristin Faye Olalo. 
Institutional Review Board Statement: Not applicable.

Informed Consent Statement: Not applicable.

Data Availability Statement: The data presented in this study are available on request from the corresponding author.

Conflicts of Interest: The authors declare no conflict of interest.

\section{References}

1. Scheinberg, A.; Spies, S.; Simpson, M.H.; Mol, A.P.J. Assessing urban recycling in low- and middle-income countries: Building on modernized mixtures. Habitat Int. 2011, 35, 188-198. [CrossRef]

2. Liamsanguan, C.; Gheewala, S.H. The holistic impact of integrated solid waste management on greenhouse gas emissions in Phuket. J. Clean. Prod. 2008, 16, 1865-1871. [CrossRef]

3. Dong, J.; Ni, M.; Chi, Y.; Zou, D.; Fu, C. Life cycle and economic assessment of source-separated MSW collection with regard to greenhouse gas emissions: A case study in China. Environ. Sci. Pollut. Res. 2013, 20, 5512-5524. [CrossRef]

4. Tan, S.T.; Lee, C.T.; Hashim, H.; Ho, W.S.; Lim, J.S. Optimal process network for municipal solid waste management in Iskandar Malaysia. J. Clean. Prod. 2014, 71, 48-58. [CrossRef]

5. Troschinetz, A.M.; Mihelcic, J.R. Sustainable recycling of municipal solid waste in developing countries. Waste Manag. 2009, 29, 915-923. [CrossRef]

6. Pandyaswargo, A.H.; Onoda, H.; Nagata, K. Energy recovery potential and life cycle impact assessment of municipal solid waste management technologies in Asian countries using ELP model. Int. J. Energy Environ. Eng. 2012, 3, 28. [CrossRef]

7. Guerrero, L.A.; Maas, G.; Hogland, W. Solid waste management challenges for cities in developing countries. Waste Manag. 2013, 33, 220-232. [CrossRef] [PubMed]

8. Menikpura, S.N.M.; Gheewala, S.H.; Bonnet, S.; Chiemchaisri, C. Evaluation of the effect of recycling on sustainability of municipal solid waste management in Thailand. Waste Biomass Valorization 2013, 4, 237-257. [CrossRef]

9. Ferronato, N.; Torretta, V. Waste mismanagement in developing countries: A review of global issues. Int. J. Environ. Res. Public Health 2019, 16, 1060. [CrossRef]

10. Kazuva, E.; Zhang, J. Analyzing municipal solid waste treatment scenarios in rapidly urbanizing cities in developing countries: The case of Dar es Salaam, Tanzania. Int. J. Environ. Res. Public Health 2019, 16, 2035. [CrossRef] [PubMed]

11. Oosterveer, P.; Spaargaren, G. Meeting social challenges in developing sustainable environmental infrastructures in East African cities. In Social Perspectives on the Sanitation Challenge; Springer: Dordrecht, The Netherlands, 2010; pp. 11-30.

12. Menikpura, S.N.M.; Sang-Arun, J.; Bengtsson, M. Integrated solid waste management: An approach for enhancing climate co-benefits through resource recovery. J. Clean. Prod. 2013, 58, 34-42. [CrossRef]

13. City Government of Davao. 10-Year Solid Waste Management Plan of Davao City for 2018-2027; City Government of Davao: Davao City, Philippines, 2017.

14. Republic of the Philippines. Republic Act 9003-The ecological solid waste management act of the Philippines 2000. In Proceedings of the Eleventh Congress of the Philippines, Third Regular Session, Quezon City, Philippines, 26 January 2001.

15. Japan International Cooperation Agency. Davao City Infrastructure Development Plan and Capacity Building Project-Final Report—Summary. 2018. Available online: http:/ / open_jicareport.jica.go.jp/pdf/12308706.pdf (accessed on 1 October 2019).

16. Japan International Cooperation Agency. Collaboration Program with the Private Sector for Disseminating Japanese Technology for Waste to Energy System in Davao City_Final Report. 2016. Available online: http://open_jicareport.jica.go.jp/pdf/12302113 .pdf (accessed on 1 October 2019).

17. Gunamantha, M.; Sarto, S. Life cycle assessment of municipal solid waste treatment to energy options: Case study of KARTAMANTUL region, Yogyakarta. Renew. Energy 2012, 41, 277-284. [CrossRef]

18. Premakumara, D.G.J.; Menikpura, S.N.M.; Singh, R.K.; Hengesbaugh, M.; Magalang, A.A.; Ildefonso, E.T.; Valdez, M.D.C.M.; Silva, L.C. Reduction of greenhouse gases (GHGs) and short-lived climate pollutants (SLCPs) from municipal solid waste management (MSWM) in the Philippines: Rapid review and assessment. Waste Manag. 2018, 80, 397-405. [CrossRef] [PubMed]

19. Chen, Y.; Cui, Z.; Cui, X.; Liu, W.; Wang, X.; Li, X.; Li, S. Life cycle assessment of end-of-life treatments of waste plastics in China. Resour. Conserv. Recycl. 2019, 146, 348-357. [CrossRef]

20. Badran, M.F.; El-Haggar, S.M. Optimization of municipal solid waste management in Port Said-Egypt. Waste Manag. 2006, 26, 534-545. [CrossRef]

21. Dai, C.; Li, Y.P.; Huang, G.H. A two-stage support-vector-regression optimization model for municipal solid waste managementA case study of Beijing, China. J. Environ. Manag. 2011, 92, 3023-3037. [CrossRef]

22. Ng, W.; Varbanov, P.; Klemeš, J.; Hegyhati, M.; Bertok, B.; Heckl, I.; Lam, H. Waste to energy for small cities: Economics versus carbon footprint. Chem. Eng. Trans. 2013, 35, 889-894. [CrossRef]

23. Rodionov, M.A.; Nakata, T. Design of an optimal waste utilization system: A case study in St. Petersburg, Russia. Sustainability 2011, 3, 1486-1509. [CrossRef]

24. Santibañez-Aguilar, J.E.; Ponce-Ortega, J.M.; Betzabe González-Campos, J.B.; Serna-González, M.; El-Halwagi, M.M. Optimal planning for the sustainable utilization of municipal solid waste. Waste Manag. 2013, 33, 2607-2622. [CrossRef] 
25. Yousefloo, A.; Babazadeh, R. Designing an integrated municipal solid waste management network: A case study. J. Clean. Prod. 2020, 244, 118824. [CrossRef]

26. Nakatani, J. Life-cycle inventory analysis of recycling: Mathematical and graphical frameworks. Sustainability 2014, 6, 6158-6169. [CrossRef]

27. Manfredi, S.; Tonini, D.; Christensen, T.H.; Scharff, H. Landfilling of waste: Accounting of greenhouse gases and global warming contributions. Waste Manag. Res. 2009, 27, 825-836. [CrossRef] [PubMed]

28. Friedrich, E.; Trois, C. GHG emission factors developed for the recycling and composting of municipal waste in South African municipalities. Waste Manag. 2013, 33, 2520-2531. [CrossRef]

29. Astrup, T.; Møller, J.; Fruergaard, T. Incineration and co-combustion of waste: Accounting of greenhouse gases and global warming contributions. Waste Manag. Res. 2009, 27, 789-799. [CrossRef] [PubMed]

30. Boldrin, A.; Andersen, J.K.; Møller, J.; Christensen, T.H.; Favoino, E. Composting and compost utilization: Accounting of greenhouse gases and global warming contributions. Waste Manag. Res. 2009, 27, 800-812. [CrossRef] [PubMed]

31. Fruergaard, T.; Astrup, T.; Ekvall, T. Energy use and recovery in waste management and implications for accounting of greenhouse gases and global warming contributions. Waste Manag. Res. 2009, 27, 724-737. [CrossRef] [PubMed]

32. Pachauri, R.K.; Allen, M.R.; Barros, V.R.; Broome, J.; Cramer, W.; Christ, R.; Church, J.A.; Clarke, L.; Dahe, Q.D.; Dasqupta, P.; et al. Climate Change 2014: Synthesis Report. Contribution of Working Groups I, II and III to the Fifth Assessment Report of the Intergovernmental Panel on Climate Change; IPCC: Geneva, Switzerland, 2014; p. 151.

33. Asian Development Bank. Materials Recovery Facility Tool Kit; Asian Development Bank: Mandaluyong City, Philippines, 2013. Available online: https:/ /www.adb.org/sites/default/files/publication/30220/materials-recovery-facility-tool-kit.pdf (accessed on 1 December 2020).

34. Japan International Cooperation Agency. Davao City Infrastructure Development Plan and Capacity Building Project Final Report Vol. 1 Part I Present Situation and Annex. 2018. Available online: http:/ / open_jicareport.jica.go.jp/pdf/12308714_01.pdf (accessed on 1 October 2019).

35. Japan International Cooperation Agency. The Study on Recycling Industry Development in the Republic of the Philippines Final Report. 2008. Available online: https:/ / openjicareport.jica.go.jp/pdf/11882404_02.pdf (accessed on 1 November 2019).

36. Japan International Cooperation Agency. Davao City Infrastructure Development Plan and Capacity Building Project Final Report Vol. 2 Part II Development Plan Part III Capacity Development. 2018. Available online: http:/ /open_jicareport.jica.go.jp/ pdf/12308722_01.pdf (accessed on 1 October 2019).

37. Department of Energy. Power Supply Procurement Plan. 2019. Available online: https://www.doe.gov.ph/sites/default/ files/ pdf/du_csp/2019-2028_DLPC_PSPP.pdf (accessed on 1 December 2020). 